\title{
ASTHMA
}

\section{Study of modifiable risk factors for asthma exacerbations: virus infection and allergen exposure increase the risk of asthma hospital admissions in children}

\author{
C S Murray, G Poletti, T Kebadze, J Morris, A Woodcock, S L Johnston, A Custovic
}

Thorax 2006;61:376-382. doi: 10.1136/thx.2005.042523

See end of article for authors' affiliations

Correspondence to Dr C S Murray, Academic Division of Medicine and Surgery South, The University of Manchester, North West Lung Centre, South Manchester University Hospitals NHS Trust, Manchester M23

9LT, UK; clare.murray@ manchester.ac.uk

Received 15 February 2005 Accepted

12 December 2005

Published Online First

29 December 2005

\begin{abstract}
Background: Asthma exacerbation is the most common cause of hospital admission in children. A study was undertaken to investigate the importance of allergen exposure in sensitised individuals in combination with viral infections and other potentially modifiable risk factors precipitating asthma hospital admission in children.

Methods: Eighty four children aged 3-17 years admitted to hospital over a 1 year period with an acute asthma exacerbation (AA) were matched for age and sex with two control groups: stable asthmatics (SA) and children admitted to hospital with non-respiratory conditions (IC). Risk factors were assessed by questionnaires and determination of allergen sensitisation, home allergen exposure, pollen exposure, and respiratory virus infection.

Results: Several non-modifiable factors (atopy, duration of asthma) were associated with increased risk. Among the modifiable factors, pet ownership, housing characteristics, and parental smoking did not differ between the groups. Regular inhaled corticosteroid treatment was significantly less common in the AA group than in the SA group (OR $0.2,95 \% \mathrm{Cl} 0.1$ to $0.6 ; \mathrm{p}=0.002$ ). A significantly higher proportion of the AA group were virus infected (44\%) and sensitised and highly exposed to sensitising allergen (76\%) compared with the SA (18\% and $48 \%$ ) and IC groups (17\% and $28 \%$; both $p<0.001)$. In a multiple conditional logistic regression ( $\mathrm{AA} v \mathrm{SA})$, allergen sensitisation and exposure or virus detection alone were no longer independently associated with hospital admission. However, the combination of virus detection and sensitisation with high allergen exposure substantially increased the risk of admission to hospital (OR $19.4,95 \% \mathrm{Cl} 3.7$ to $101.5, \mathrm{p}<0.001$ ).

Conclusions: Natural virus infection and real life allergen exposure in allergic asthmatic children increase the risk of hospital admission. Strategies for preventing exacerbations will need to address these factors.
\end{abstract}

A sthma is one of the common causes of acute admission to hospital in children. Current treatments, although helpful, are still unable to prevent childhood asthma exacerbations completely. ${ }^{1}$ In order to improve asthma management it is essential to understand clearly the causes of exacerbations leading to hospital admission which are amenable for intervention. Previous admission to hospital with asthma ${ }^{23}$ and sensitisation to indoor allergens increase the risk of hospital admission, ${ }^{45}$ but neither is modifiable. The association between virus infections and exacerbation of asthma in children was initially demonstrated using culture and serological methods, ${ }^{6}$ and subsequently confirmed by similar or more modern techniques. ${ }^{7-11}$ Viruses were detected using polymerase chain reaction in $\sim 80 \%$ of asthma exacerbations in children. ${ }^{12}$ One of the other factors associated with increased emergency room visits and hospital admissions with asthma attacks in children is high exposure to allergens. ${ }^{13}{ }^{14}$ Experimental data suggest a synergistic interaction between allergens and viruses. ${ }^{15}$

Although the interactions of allergen sensitisation with virus infection ${ }^{4}$ and with high exposure to specific allergen ${ }^{5}$ have been reported previously, no study to date has investigated the relationship between all three factors in childhood exacerbations. We carried out a case-control study investigating the importance of exposure in sensitised individuals in combination with viral infection precipitating acute asthma attacks resulting in hospital admission in children. We also investigated other risk factors that are potentially modifiable in order to help determine where preventive strategies should be focused in the future.

\section{METHODS}

\section{Participants}

The study was carried out in the South Manchester University Hospital over a 12 month period. Children aged 3-17 years admitted to hospital with an acute asthma exacerbation (asthma admission, AA) were matched for age ( \pm 2 years) and sex with two control groups: (1) patients with stable asthma who were not admitted to hospital and did not require oral steroids for asthma exacerbation within the previous 12 months (stable asthma, SA; recruited from the outpatient department); and (2) patients admitted to hospital with non-respiratory conditions (inpatient control, IC). Controls were enrolled within 3 weeks of recruitment of the index case.

The study was approved by the local research ethics committee and informed consent was obtained from all parents (and children when appropriate).

Abbreviations: AA, acute asthma; IC, inpatient control; OR, odds ratio; PCR, polymerase chain reaction; PG, pollen grain; $S A$, stable asthma 


\section{Outcomes}

Information was collected on medication use, housing conditions, family history, parental smoking, pet ownership, and previous hospital admissions using validated respiratory and environmental questionnaires. ${ }^{16}$

Sensitisation status was ascertained using skin prick testing (Dermatophagoides pteronyssinus, cat, dog, mixed grasses, negative and positive controls; Bayer, Elkahrt, IN, USA). Sensitisation was defined as a weal diameter $3 \mathrm{~mm}$ greater than negative control. We also measured total and specific serum IgE (mite, cat, dog, ryegrass; UniCAP, Pharmacia, Uppsala, Sweden) and defined sensitisation as a concentration of allergen specific IgE of $>0.35 \mathrm{kU} / \mathrm{l}$.

Nasal lavage fluid for virus detection was collected within 24 hours of recruitment using a 12 Fr balloon catheter. The tube was inserted into the nostril, the balloon inflated, and $2 \mathrm{ml}$ sterile saline instilled for 30 seconds and then aspirated. The lavage fluid was mixed with $2 \mathrm{ml}$ sterile viral culture medium, immediately frozen on dry ice, and stored at $-70^{\circ} \mathrm{C}$. Samples were analysed by polymerase chain reaction (PCR) for picornaviruses (rhinoviruses and enteroviruses), coronaviruses, respiratory syncytial virus, influenza $A$ and $B$, parainfluenza viruses 1-3, adenoviruses, Chlamydia and Mycoplasma pneumoniae. The methods were adapted from those published. ${ }^{17}$ Details of target genes, primer sequences, and cycling variables are available on request. All samples were analysed blinded to groups.

Indoor allergen levels (Der $p$ l, Fel d 1, Can $f$ l) were measured using monoclonal antibody based enzyme linked immunoassays in the dust samples taken from the child's mattress and living-room floor, which were collected within 2 weeks of recruitment.

Grass pollen exposure was estimated using pollen counts (number of pollen grains per cubic metre of air sampled $(\mathrm{PG}) / \mathrm{m}^{3}$ ) averaged over 24 hours) which were obtained from the UK Pollen Monitoring Network local site.

\section{Statistical analysis}

With 84 matched subjects, an odds ratio (OR) of 2.5 or more for the potential risk factor(s) could be detected with $85 \%$ power at a significance level of $5 \%$, assuming an underlying exposure rate to any of the risk factors of $50 \%$.

Comparisons of groups AA $v$ SA and AA $v$ IC with respect to individual risk factors were carried out using conditional logistic regression using Stata Version 6.0 (Stata Corp, College Station, TX, USA). This analysis gave appropriate adjustment for the one-to-one matching of the groups. In order to investigate the effect of individual or combinations of sensitisation, exposure to sensitising allergen and viral infection, a constructed variable was created which was stratified for the presence and combination of factors (sensitised only; virus detected only; sensitised and exposed only; sensitised and virus detected only; sensitised and exposed and virus detected (that is, mutually exclusive categories); reference category neither sensitised nor virus detected $( \pm$ exposed $)$ ). Multiple conditional logistic regression analysis was then used to assess the significance of various factors adjusting for the influence of other variables which were shown to be significantly associated with the AA group in the univariate analysis. The results are presented as ORs with 95\% confidence intervals (95\% CI). ORs were calculated for both categorical (usually presence/absence) and continuous variables. For the former, the OR simply shows the increased or decreased risk of asthma admission with the presence of the risk factor; for the latter, the OR shows the multiplicative increased or decreased risk with each unit (or log unit) increase.

The problem of multiple comparisons, given the number of risk factors considered and the inherent increased likelihood of obtaining significant results by chance, is acknowledged. Hence, for the univariate analyses group differences are interpreted as being significantly different only for $\mathrm{p}$ values $<0.01$.

High exposure to dust mite, cat or dog allergen was considered when Der $p \mathrm{l}>2 \mu \mathrm{g} / \mathrm{g},{ }^{18} \mathrm{Fel} d \mathrm{l}>8 \mu \mathrm{g} / \mathrm{g},{ }^{19}$ and Can $f \mathrm{l}>10 \mu \mathrm{g} / \mathrm{g} .{ }^{20}$ These values were used to divide study participants into those "exposed" or "not exposed" to each allergen. The pollen count was given as low, moderate, high, or very high based on the following cut off levels: low $<30 \mathrm{PG} / \mathrm{m}^{3}$; moderate $30-49 \mathrm{PG} / \mathrm{m}^{3}$; high 50-149 PG $/ \mathrm{m}^{3}$; very high $>150 \mathrm{PG} / \mathrm{m}^{3}$. Children were classified as exposed to grass pollen if the average pollen count for the 7 days before the date they were recruited was classed as high or very high.

\section{RESULTS \\ Participants}

Eighty four of 125 children (55 (65.5\%) boys, mean age 7.04 years) admitted to hospital for an asthma exacerbation between 1 February 2000 and 31 January 2001 were recruited into the study with matching controls. Of the 41 who did not take part, 10 parents declined to give informed consent and the remaining 31 were unable to give consent because the parents were not present in the hospital. There was no difference in age and sex between the children who took part and those who did not. Six participants (two boys, age range 3-16 years) were readmitted during the course of the study but were not included again. The largest number of admissions occurred in September $(n=18)$, followed by June and July $(n=11)$, and the fewest in August $(n=2)$.

Forty eight children in the SA control group had had at least one previous hospital admission with an asthma exacerbation compared with 59 in the AA group (table 1, $\mathrm{p}=0.12$ ). There was no significant difference in the number of previous asthma admissions between the two groups $(\mathrm{p}=0.88)$.

\section{Non-modifiable risk factors}

The risk factors not amenable to intervention in the three study groups are shown in table 1. There were no significant differences between the groups in ethnicity. Children in both asthma groups (AA and SA) were more likely to have eczema and hay fever than children without asthma (IC), with no difference between AA and SA. The proportion of sensitised children differed significantly between the three groups with children in the AA group being more likely to be skin test positive to at least one allergen than those in the SA (OR 3.6, $95 \%$ CI 1.7 to $7.9, \mathrm{p}=0.001$ ) or IC group (OR 16.3, 95\% CI 5.1 to $52, \mathrm{p}<0.001)$. This pattern was similar for each allergen but reached statistical significance between the AA and SA groups only for dog. Levels of total and allergen specific IgE were higher in the AA group, but this difference reached significance only between the AA and IC groups.

\section{Modifiable risk factors}

The potentially modifiable risk factors in the three study groups are shown in table 2 . There were no significant differences between the groups in maternal or paternal smoking, pet ownership, housing characteristics, and deprivation index score. Regular inhaled corticosteroid (ICS) treatment was significantly less common in the AA group than in the SA group (OR $0.2,95 \%$ CI 0.1 to $0.6, p=0.002$ ).

\section{Virus detection}

Sixty nine children had a virus detected in their nasal washing (44\% in the AA group, $17.9 \%$ in the SA group, and $16.7 \%$ in the IC group, $p<0.001$ ). Rhinoviruses were the most commonly detected respiratory pathogens accounting for $81 \%$ of viruses detected in the AA group; they were the only 
Table 1 Non-modifiable risk factors for hospital admission with acute asthma

\begin{tabular}{|c|c|c|c|c|c|}
\hline & $\begin{array}{l}\text { Asthma } \\
\text { admissions (AA) } \\
\text { ( } \mathrm{n}=84 \text { ) }\end{array}$ & $\begin{array}{l}\text { Stable } \\
\text { asthma (SA) } \\
(n=84)\end{array}$ & $\begin{array}{l}\text { Inpatient } \\
\text { control (IC) } \\
(n=84)\end{array}$ & Odds ratio $(95 \% \mathrm{Cl})^{*}$ & $p$ value* \\
\hline White ethnicity & 71 (84.5\%) & $78(92.9 \%)$ & $75(89.3 \%)$ & $\begin{array}{l}\text { AA } v \text { SA: } 0.5(0.2 \text { to } 1.2) \\
A A \vee I C: 0.7(0.3 \text { to } 1.6)\end{array}$ & $\begin{array}{l}0.12 \\
0.37\end{array}$ \\
\hline Maternal asthma & $21(25.0 \%)$ & $33(39.3 \%)$ & $11(13.1 \%)$ & $\begin{array}{l}\text { AA } v \text { SA: } 0.5(0.3 \text { to } 1.0) \\
\text { AA } v \text { IC: } 2.0(0.9 \text { to } 4.3)\end{array}$ & $\begin{array}{l}0.06 \\
0.07\end{array}$ \\
\hline $\begin{array}{l}\text { Previous hospital asthma } \\
\text { admission }\end{array}$ & $59(70.2 \%)$ & $48(57.1 \%)$ & $0(0 \%)$ & $\begin{array}{l}\text { AA } v \text { SA: } 1.6 \text { (0.9 to } 2.8) \\
\text { AA } v \text { IC. OR not defined }\end{array}$ & 0.12 \\
\hline Duration of asthma† & $3.1(0.1-14.7)$ & $4.7(0.4-15.2)$ & - & $\begin{array}{l}\text { AA } v \text { SA: } 0.8(0.7 \text { to } 0.9) \neq \\
\text { AA } v \text { IC: OR not defined }\end{array}$ & 0.004 \\
\hline Hay fever & $25(29.8 \%)$ & $29(34.5 \%)$ & $8(9.5 \%)$ & $\begin{array}{l}\text { AA } \vee \text { SA: } 0.8(0.4 \text { to } 1.5) \\
\text { AA } \vee \text { IC: } 3.4(1.5 \text { to } 8.0)\end{array}$ & $\begin{array}{l}0.51 \\
0.004\end{array}$ \\
\hline Eczema & $48(57.1 \%)$ & $47(56.0)$ & $15(17.9 \%)$ & $\begin{array}{l}\text { AA } v \text { SA: } 1.1(0.6 \text { to } 2.0) \\
\text { AA } v \text { IC: } 7.6(3.0 \text { to } 19.3)\end{array}$ & $\begin{array}{l}0.87 \\
<0.001\end{array}$ \\
\hline \multicolumn{6}{|l|}{ Atopy: skin tests } \\
\hline At least 1 allergen & $72(85.7 \%)$ & $51(60.7 \%)$ & $26(31.0 \%)$ & $\begin{array}{l}\text { AA } v \text { SA: } 3.6(1.7 \text { to } 7.9) \\
\text { AA } v \text { IC: } 16.3(5.1 \text { to } 52)\end{array}$ & $\begin{array}{l}0.001 \\
<0.001\end{array}$ \\
\hline House dust mite & $56(66.7 \%)$ & $44(52.4 \%)$ & $23(27.4 \%)$ & $\begin{array}{l}\text { AA } v \text { SA: } 1.8(0.9 \text { to } 3.2) \\
\text { AA } v \text { IC: } 5.7(2.6 \text { to } 12.8)\end{array}$ & $\begin{array}{l}0.07 \\
<0.001\end{array}$ \\
\hline Cat & $36(42.9 \%)$ & $28(33.3 \%)$ & $4(4.8 \%)$ & $\begin{array}{l}\text { AA } v \text { SA: } 1.6(0.8 \text { to } 3.1) \\
\text { AA } v \text { IC: } 17(4.1 \text { to } 71.0)\end{array}$ & $\begin{array}{l}0.19 \\
<0.001\end{array}$ \\
\hline Dog & $32(38.1 \%)$ & $17(20.2 \%)$ & $2(2.4 \%)$ & $\begin{array}{l}\text { AA } \vee \text { SA: } 2.4 \text { (1.2 to } 4.8) \\
\text { AA } v \text { IC: OR not defined }\end{array}$ & $\begin{array}{l}0.017 \\
<0.001\end{array}$ \\
\hline Pollen & $48(57.1 \%)$ & $40(47.6 \%)$ & $16(19.0 \%)$ & $\begin{array}{l}\text { AA } \vee \text { SA: } 1.5(0.8 \text { to } 2.9) \\
\text { AA } v \text { IC: } 9.0(3.2 \text { to } 25.3)\end{array}$ & $\begin{array}{l}0.20 \\
<0.001\end{array}$ \\
\hline \multicolumn{6}{|c|}{ Atopy: IgE (GM and range; $k U / l)$} \\
\hline Total lgE & $\begin{array}{l}438.8 \\
(5.0-6036)\end{array}$ & $\begin{array}{l}183.4 \\
(2.0-9775)\end{array}$ & $\begin{array}{l}55.7 \\
(2.0-4905)\end{array}$ & $\begin{array}{l}\text { AA } v \text { SA: } 1.20(0.94 \text { to } 1.53) \\
\text { AA } v \text { IC: } 1.77 \text { (1.29 to } 2.43)\end{array}$ & $\begin{array}{l}0.14 \\
<0.001\end{array}$ \\
\hline Specific $\lg E$ mite & $\begin{array}{l}20.3 \\
(0.35-955)\end{array}$ & $\begin{array}{l}5.2 \\
(0.35-988)\end{array}$ & $\begin{array}{l}0.79 \\
(0.35-251)\end{array}$ & $\begin{array}{l}\text { AA } \vee \text { SA: } 1.13(0.98 \text { to } 1.30) \\
\text { AA } \vee \text { IC: } 1.59(1.23 \text { to } 2.06)\end{array}$ & $\begin{array}{l}0.09 \\
<0.001\end{array}$ \\
\hline Specific lgE cat & $\begin{array}{l}1.64 \\
(0.35-177)\end{array}$ & $\begin{array}{l}1.0 \\
(0.35-356)\end{array}$ & $\begin{array}{l}0.39 \\
(0.35-6.53)\end{array}$ & $\begin{array}{l}\text { AA } \vee \text { SA: } 1.09(0.90 \text { to } 1.32) \\
\text { AA } \vee \text { IC: } 2.64(1.20 \text { to } 5.81)\end{array}$ & $\begin{array}{l}0.40 \\
0.016\end{array}$ \\
\hline Specific lgE dog & $\begin{array}{l}2.3 \\
(0.35-654)\end{array}$ & $\begin{array}{l}1.2 \\
(0.35-366)\end{array}$ & $\begin{array}{l}0.40 \\
(0.35-13.5)\end{array}$ & $\begin{array}{l}\text { AA } \vee \text { SA: } 1.09(0.89 \text { to } 1.32) \\
\text { AA } \vee \text { IC: } 2.20(1.25 \text { to } 3.89)\end{array}$ & $\begin{array}{l}0.40 \\
0.007\end{array}$ \\
\hline Specific lgE rye & $\begin{array}{l}3.6 \\
(0.5-959)\end{array}$ & $\begin{array}{l}2.2 \\
(0.35-428)\end{array}$ & $\begin{array}{l}0.53 \\
(0.35-187)\end{array}$ & $\begin{array}{l}\text { AA } \vee \text { SA: } 1.03(0.87 \text { to } 1.22) \\
\text { AA } \vee \text { IC: } 1.73(1.17 \text { to } 2.57)\end{array}$ & $\begin{array}{l}0.76 \\
0.006\end{array}$ \\
\hline
\end{tabular}

virus type detected more frequently in the AA group than the other groups (fig 1). Children in the AA group were significantly more likely to have a virus detected than those in the SA (OR 5.4, 95\% CI 2.1 to $14.0, \mathrm{p}=0.001$ ) or IC groups (OR $4.3,95 \%$ CI 1.9 to $9.8, p=0.001$ ). Viruses were most commonly detected from August through to November, with levels of detection of $50-100 \%$ in children in the AA group in these months (fig 2).

\section{Allergen exposure}

Dust samples were obtained from both sampling sites in 250 homes. Samples were not available for two cases (home access not gained); these two cases and their controls were excluded from the exposure analyses. There were no differences in the concentrations of mite, cat and dog allergen in either of the sampling sites between the study groups (full data available on request). Grass pollen was only detectable from early May to mid October. However, levels of more than $50 \mathrm{PG} / \mathrm{m}^{3}$ (high or very high) were detected from early June to mid July (full data available on request). Children in the AA group were no more likely to be exposed to any one of the allergens than those in either the SA group (OR 1.6, 95\% CI 0.5 to $4.9, \mathrm{p}=0.41$ ) or IC group (OR $0.7,95 \%$ CI 0.2 to $2.4, \mathrm{p}=0.53)$.

\section{Combination of sensitisation and exposure to sensitising allergen}

Children were classed by the presence of a positive skin test to an allergen (sensitised) and whether they were exposed to high levels of sensitising allergen (table 2). Children in the AA group were significantly more likely to be sensitised and exposed to at least one allergen than those in the SA (OR 2.9, $95 \%$ CI 1.5 to $5.6, \mathrm{p}=0.001$ ) or IC groups (OR $10.8,95 \% \mathrm{CI}$ 3.9 to $29.9, \mathrm{p}<0.001)$.

\section{Combination of sensitisation and exposure to sensitising allergen and virus detection}

A significant difference was observed between the groups with respect to the combination of sensitisation and exposure to at least one sensitising allergen and virus detection $(35.4 \%$ in the AA group, $7.3 \%$ in the SA group, and $2.4 \%$ in the IC group, $\mathrm{p}<0.001)$. Children in the AA group were at a significantly higher risk of being sensitised and exposed to the sensitising allergen and having a respiratory pathogen detectable than those in the SA (OR 8.7, 95\% CI 2.6 to 28.6, $\mathrm{p}<0.001$ ) or IC group (OR 28.0, 95\% CI 3.8 to $206, \mathrm{p}=0.001$ ). A similar pattern was seen in AA children who were sensitised and exposed to the sensitising allergen and had rhinovirus present compared with SA children (OR 23.0, 95\% CI 3.1 to $170, p=0.002$ ), although confidence intervals were large due to the smaller numbers of children (table 2 ).

In order to establish the ORs of individual and combined factors, children were assigned to specific groups within a constructed variable adjusting for the presence or absence of individual factors (sensitised only, virus only, sensitised and exposed only, sensitised and virus only, sensitised and exposed and virus). Children in the AA group were at a significantly higher risk of being sensitised and exposed to 
Table 2 Potentially modifiable risk factors for hospital admission

\begin{tabular}{|c|c|c|c|c|c|}
\hline & $\begin{array}{l}\text { Asthma } \\
\text { admissions (AA) }\end{array}$ & $\begin{array}{l}\text { Stable } \\
\text { asthma (SA) }\end{array}$ & $\begin{array}{l}\text { Inpatient } \\
\text { control (IC) }\end{array}$ & Odds ratio $(95 \% \mathrm{Cl})^{*}$ & p value* \\
\hline IMD, geometric mean (range) & $5284(67-30142)$ & $5029(256-32230)$ & $6423(188-32308)$ & $\begin{array}{l}\text { AA } v \text { SA: } 1.0(0.8 \text { to } 1.3) \\
\text { AA } v \text { IC: } 0.9(0.7 \text { to } 1.1)\end{array}$ & $\begin{array}{l}0.83 \\
0.38\end{array}$ \\
\hline \multicolumn{6}{|l|}{ ETS exposure } \\
\hline Maternal smoking & $29(34.5 \%)$ & $35(41.7 \%)$ & $32(38.1 \%)$ & $\begin{array}{l}\text { AA } v \text { SA: } 0.7(0.4 \text { to } 1.4) \\
\text { AA } v \text { IC: } 0.9(0.4 \text { to } 1.6)\end{array}$ & $\begin{array}{l}0.32 \\
0.62\end{array}$ \\
\hline Paternal smoking & $31(36.9 \%)$ & $28(33.3 \%)$ & $28(33.3 \%)$ & $\begin{array}{l}\text { AA } \vee \text { SA: } 1.2(0.6 \text { to } 2.3) \\
\text { AA } v \text { IC: } 1.1(0.6 \text { to } 2.1)\end{array}$ & $\begin{array}{l}0.61 \\
0.66\end{array}$ \\
\hline \multicolumn{6}{|l|}{ Pet ownership } \\
\hline Dog owners & $20(23.8 \%)$ & $23(27.4 \%)$ & $28(33.3 \%)$ & $\begin{array}{l}\text { AA } v \text { SA: } 0.8(0.4 \text { to } 1.7) \\
\text { AA } v \text { IC: } 0.6(0.3 \text { to } 1.2)\end{array}$ & $\begin{array}{l}0.56 \\
0.17\end{array}$ \\
\hline Cat owners & $15(17.9 \%)$ & $21(25 \%)$ & $21(25 \%)$ & $\begin{array}{l}\text { AA } \vee \text { SA: } 0.7(0.3 \text { to } 1.4) \\
\text { AA } \vee \text { IC: } 0.7(0.3 \text { to } 1.4)\end{array}$ & $\begin{array}{l}0.26 \\
0.26\end{array}$ \\
\hline \multicolumn{6}{|l|}{ Housing conditions } \\
\hline Central heating & $82(97.6 \%)$ & $82(97.6 \%)$ & $80(95.2 \%)$ & $\begin{array}{l}\text { AA v SA: } 1.0(0.1 \text { to } 7.1) \\
\text { AA } v \text { IC: } 2.0(0.4 \text { to } 10.9)\end{array}$ & $\begin{array}{l}1.0 \\
0.42\end{array}$ \\
\hline Double glazing & $41(48.8 \%)$ & $32(38.1 \%)$ & $34(40.5 \%)$ & $\begin{array}{l}\text { AA } \vee \text { SA: } 1.6(0.8 \text { to } 3.2) \\
\text { AA } \vee \text { IC: } 1.5(0.8 \text { to } 2.8)\end{array}$ & $\begin{array}{l}0.14 \\
0.25\end{array}$ \\
\hline Own bedroom & $44(52.4 \%)$ & $52(61.9 \%)$ & $56(66.7 \%)$ & $\begin{array}{l}\text { AA } v \text { SA: } 1.5(0.8 \text { to } 2.8) \\
\text { AA } v \text { IC: } 1.8(1.0 \text { to } 3.2)\end{array}$ & $\begin{array}{l}0.21 \\
0.07\end{array}$ \\
\hline Own bed & $80(95.2 \%)$ & 79 (94.0\%) & $82(97.6 \%)$ & $\begin{array}{l}\text { AA } \vee \text { SA: } 1.3(0.3 \text { to } 6.0) \\
\text { AA } \vee \text { IC: } 0.5(0.1 \text { to } 2.7)\end{array}$ & $\begin{array}{l}0.71 \\
0.42\end{array}$ \\
\hline $\begin{array}{l}\text { Condensation on bedroom } \\
\text { window }\end{array}$ & $47(56.0 \%)$ & $46(54.8 \%)$ & $46(54.8 \%)$ & $\begin{array}{l}\text { AA } \vee \text { SA: } 1.1(0.6 \text { to } 2.0) \\
\text { AA } v \text { IC: } 1.0(0.6 \text { to } 1.9)\end{array}$ & $\begin{array}{l}0.87 \\
0.88\end{array}$ \\
\hline Damp/mould in bedroom & $4(4.8 \%)$ & $4(4.8 \%)$ & $1(1.2 \%)$ & $\begin{array}{l}\text { AA } v \text { SA: } 1.0(0.3 \text { to } 4.0) \\
\text { AA } v \text { IC: } 4.0(0.5 \text { to } 35.8)\end{array}$ & $\begin{array}{l}1.0 \\
0.22\end{array}$ \\
\hline \multicolumn{6}{|l|}{ Indication of asthma severity } \\
\hline On regular ICS & $52(61.9 \%)$ & 71 (84.5\%) & $0(0 \%)$ & $\begin{array}{l}\text { AA } v \text { SA } 0.24(0.10 \text { to } 0.59) \\
\text { AA } v \text { IC: not defined }\end{array}$ & $\begin{array}{l}0.002 \\
-\end{array}$ \\
\hline On additional controller & $11(13.1 \%)$ & $20(23.8 \%)$ & $0(0 \%)$ & $\begin{array}{l}\text { AA } \vee \text { SA: } 0.47(0.20 \text { to } 1.1) \\
\text { AA } \vee \text { IC: not defined }\end{array}$ & 0.08 \\
\hline Daily wheeze symptoms & $12(14.3 \%)$ & $13(15.5 \%)$ & $0(0 \%)$ & $\begin{array}{l}\text { AA } \vee \text { SA: } 0.92(0.40 \text { to } 2.1) \\
\text { AA } \vee \text { IC: not defined }\end{array}$ & 0.84 \\
\hline \multicolumn{6}{|l|}{ Virus detection† } \\
\hline Any respiratory pathogen & $37(44 \%)$ & 15 (17.9\%) & $14(16.7 \%)$ & $\begin{array}{l}\text { AA } v \text { SA: } 5.4(2.1 \text { to } 14.0) \\
\text { AA } \vee \text { IC: } 4.3(1.9 \text { to } 9.8)\end{array}$ & $\begin{array}{l}0.001 \\
0.001\end{array}$ \\
\hline Rhinovirus & $30(35.7 \%)$ & $8(9.5 \%)$ & $6(7.1 \%)$ & $\begin{array}{l}\text { AA } v \text { SA: } 8.3(2.5 \text { to } 27.6) \\
\text { AA } v \text { IC: } 7.0(2.5 \text { to } 19.9)\end{array}$ & $\begin{array}{l}0.001 \\
<0.001\end{array}$ \\
\hline \multicolumn{6}{|l|}{ Exposure to allergens } \\
\hline $\operatorname{Der} p 1, \mu \mathrm{g} / \mathrm{g}, \mathrm{GM}$ (range) $\ddagger$ & $3.83(0.05-1250)$ & $2.96(0.05-98)$ & $4.73(0.05-190)$ & $\begin{array}{l}\text { AA } \vee \text { SA: } 1.3(0.9 \text { to } 1.2) \\
\text { AA } \vee \text { IC: } 1.0(0.9 \text { to } 1.1)\end{array}$ & $\begin{array}{l}0.44 \\
0.54\end{array}$ \\
\hline Fel d 1, $\mu \mathrm{g} / \mathrm{g}, \mathrm{GM}$ (range) $\S$ & $1.06(0.05-1950)$ & $2.05(0.05-1080)$ & $1.38(0.05-1140)$ & $\begin{array}{l}\text { AA } \vee \text { SA: } 0.9(0.8 \text { to } 1.0) \\
\text { AA } \vee \text { IC: } 1.0(0.9 \text { to } 1.1)\end{array}$ & $\begin{array}{l}0.13 \\
0.47\end{array}$ \\
\hline Can $f 1, \mu g / g, G M$ (range)s & $2.23(0.05-3450)$ & $2.18(0.05-720)$ & $3.44(0.05-1650)$ & $\begin{array}{l}\text { AA } \vee \text { SA: } 1.0(0.9 \text { to } 1.1) \\
\text { AA } \vee \text { IC: } 0.9(0.8 \text { to } 1.1)\end{array}$ & $\begin{array}{l}0.83 \\
0.28\end{array}$ \\
\hline Exposed to any allergen & $76 / 82(92.7 \%)$ & $75 / 84(89.3 \%)$ & $79 / 84(94.0 \%)$ & $\begin{array}{l}\text { AA } \vee \text { SA: } 1.6(0.5 \text { to } 4.9) \\
A A \vee I C: 0.7(0.2 \text { to } 2.4)\end{array}$ & $\begin{array}{l}0.41 \\
0.53\end{array}$ \\
\hline \multicolumn{6}{|c|}{ Sensitisation and exposure to allergens } \\
\hline Any allergen & $62 / 82(75.6 \%)$ & $39 / 82(47.6 \%)$ & $23 / 82(28.0 \%)$ & $\begin{array}{l}\text { AA } v \text { SA: } 2.9(1.5 \text { to } 5.6) \\
\text { AA } v \text { IC: } 10.8(3.9 \text { to } 29.9)\end{array}$ & $\begin{array}{l}0.001 \\
<0.001\end{array}$ \\
\hline Dust mite & $47 / 82(57.3 \%)$ & $35 / 82(42.7 \%)$ & $20 / 82(24.4 \%)$ & $\begin{array}{l}\text { AA } \vee \text { SA: } 1.6(0.9 \text { to } 2.9) \\
\text { AA } \vee \text { IC: } 3.7(1.8 \text { to } 7.4)\end{array}$ & $\begin{array}{l}0.09 \\
<0.001\end{array}$ \\
\hline Cat & $9 / 82(11.0 \%)$ & $9 / 82(11.0 \%)$ & $0 / 82(0 \%)$ & $\begin{array}{l}\text { AA } \vee \text { SA: } 1.0(0.4 \text { to } 2.7) \\
\text { AA } \vee \text { IC: not defined }\end{array}$ & 1.0 \\
\hline Dog & $10 / 82(12.2 \%)$ & $4 / 82(4.9 \%)$ & $1 / 82(1.2 \%)$ & $\begin{array}{l}\text { AA } \vee \text { SA: } 2.5(0.8 \text { to } 8.0) \\
A A \vee I C: 10.0(1.3 \text { to } 78.0)\end{array}$ & $\begin{array}{l}0.12 \\
0.028\end{array}$ \\
\hline Pollen & $14 / 84(16.7 \%)$ & $4 / 82(4.9 \%)$ & $3 / 82(3.7 \%)$ & $\begin{array}{l}\text { AA } v \text { SA: } 6.0(1.3 \text { to } 27.0) \\
\text { AA } v \text { IC: not defined }\end{array}$ & 0.019 \\
\hline Sensitisation, exposure and respi & atory pathogen detect & & & & \\
\hline Any allergen and any pathogen ${ }^{*}$ & $29 / 82(35.4 \%)$ & $6 / 82(7.3 \%)$ & $2 / 82(2.4 \%)$ & $\begin{array}{l}\text { AA } v \text { SA: } 8.7(2.6 \text { to } 28.6) \\
\text { AA } v \text { IC: } 28.0(3.8 \text { to } 206)\end{array}$ & $\begin{array}{l}<0.001 \\
0.001\end{array}$ \\
\hline Any allergen and rhinovirus & $24 / 82(29.3 \%)$ & $2 / 82(2.4 \%)$ & $1 / 82(1.2 \%)$ & $\begin{array}{l}\text { AA } v \text { SA: } 23.0(3.1 \text { to } 170) \\
\text { AA } \vee \text { IC: } 24.0(3.2 \text { to } 177)\end{array}$ & $\begin{array}{l}0.002 \\
0.002\end{array}$ \\
\hline $\begin{array}{l}\text { IMD, index of multiple deprivatio } \\
{ }^{*} \text { Comparisons of groups (AA } v S \\
\text { †Frequency of respiratory pathog } \\
\text { fDer } p 1 \text { level in child's mattress } \\
\$ F e / d 1 \text { and Can } \mathrm{f} 1 \text { levels, loun } \\
\text {-Proportion of subjects sensitised } \\
\text { dust, }>10 \mu \mathrm{g} \text { Can } \mathrm{f} 1 / \mathrm{g} \text { dust, a } \\
\text { **Proportion of subjects sensitised } \\
\text { in nasal washing sample by PCR }\end{array}$ & $\begin{array}{l}\text { ETS, environmental } t \\
\text {; AA } v \text { IC): conditionc } \\
\text { in detected in nasal w } \\
\text { e floor. } \\
\text { assessed by skin prick } \\
\text { rage pollen count hig } \\
\text { assessed by spin prick } \\
\text { echnique. }\end{array}$ & $\begin{array}{l}\text { acco smoke; ICS, inho } \\
\text { ogistic regression. } \\
\text { ing sample by PCR te } \\
\text { ting) and exposed to } \\
r \text { very high on } 7 \text { days } \\
\text { ting) and exposed to } h\end{array}$ & $\begin{array}{l}\text { led corticosteroid. } \\
\text { chnique. } \\
\text { high levels of the sen } \\
\text { preceding admissio } \\
\text { igh levels of the sens }\end{array}$ & $\begin{array}{l}\text { ising allergen }(>2 \mu \mathrm{g} \text { Der } p 1 \\
\text { ing allergen and having a resp }\end{array}$ & $\begin{array}{l}\mu \mathrm{g} \mathrm{Fel} d \mathrm{~d} / \mathrm{g} \\
\text { ogen detected }\end{array}$ \\
\hline
\end{tabular}




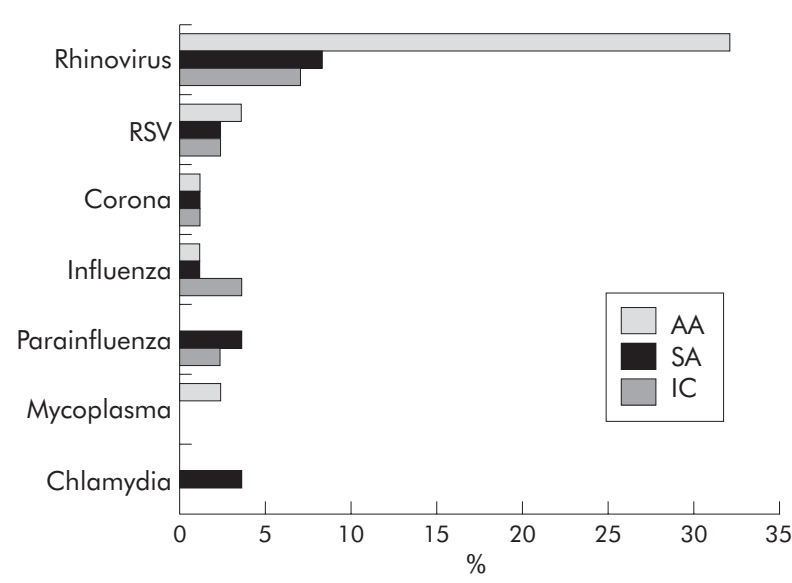

Figure 1 Respiratory pathogens detected in the admitted asthmatic (AA), stable asthmatic (SA), and non-asthmatic inpatient control (IC) groups.

the sensitising allergen and having a virus detectable than children in the SA group (OR 22.7, 95\% CI 4.6 to 112.5 , $\mathrm{p}<0.001)$. However, other individual or combination variables failed to reach significance (table 3 ).

\section{Multivariate analysis of risk factors for hospital admission}

Further analysis of risk factors for hospital admission within the two groups of asthmatic patients (AA and SA) was carried out using multiple conditional logistic regression adjusting for other risk factors that had been significant in the univariate analysis (use of inhaled corticosteroids and duration of asthma symptoms). The combination of sensitisation and exposure to high levels of sensitising allergen and virus detection remained a significant independent risk factor for hospital admission (OR 19.4, 95\% CI 3.7 to 101.5, $\mathrm{p}<0.0001$; table 3 ). The regular use of inhaled corticosteroids had a protective effect on hospital admission (OR 0.3, 95\% CI 0.1 to $0.9, \mathrm{p}=0.03$ ) whereas duration of asthma no longer affected admission (OR 0.9, 95\% CI 0.8 to $1.1, \mathrm{p}=0.3$ ).

\section{DISCUSSION}

Admission to hospital is an important risk factor for death from asthma. ${ }^{21}$ In addition, much of the cost that asthma inflicts on society ( $1-2 \%$ of the total health budgets in direct costs) results from hospital admissions. In spite of this, little is known about the causes of acute asthma exacerbations resulting in hospital admission. Knowledge of the potentially modifiable risk factors is essential for the development of strategies to prevent admissions. In this study we report that hospital admissions in children with asthma exacerbations are associated with a combination of both sensitisation and current high exposure to sensitising allergen and the presence of virus infection. Their combined effect is greater than the individual effects, suggesting a possible synergism between virus infection and allergen exposure in sensitised patients.

In this study we also identified regular use of an inhaled corticosteroid as a protective factor. Benefits from regular inhaled corticosteroids in preventing exacerbations in children with persistent asthma have been clearly demonstrated.22 23 Similarly, regular use of low dose inhaled corticosteroids is associated with a decreased risk of death from asthma in 5-44 year old patients. ${ }^{24}$ However, it has to be emphasised that there are no reported benefits from regular inhaled corticosteroids in patients only with intermittent virus induced wheezing, ${ }^{125}$ and it is likely that at least a

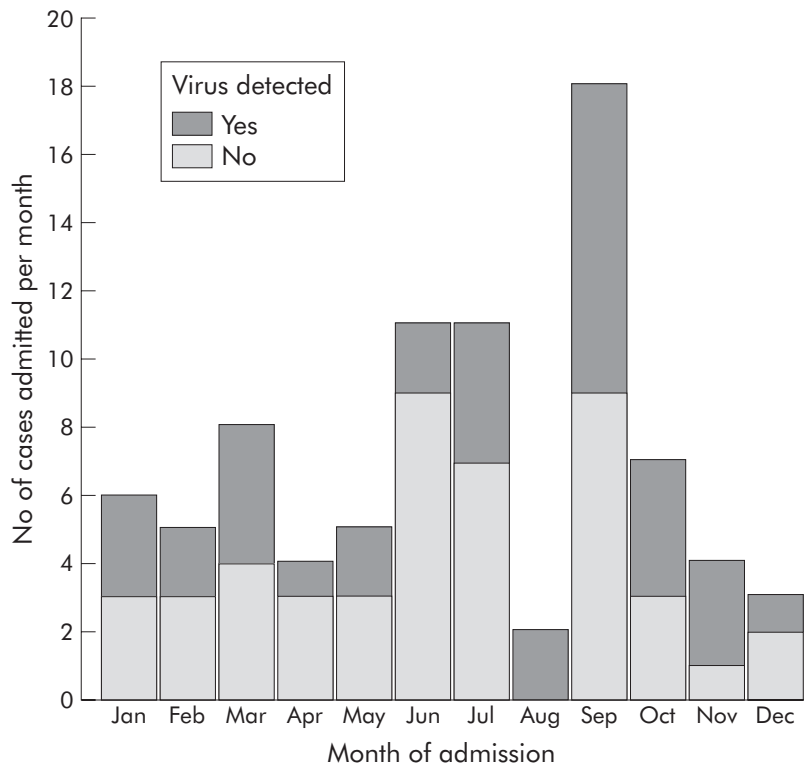

Figure 2 Number of asthma admissions per month and the proportion in whom a virus was detected.

component of virus induced wheezing is relatively resistant to steroids. ${ }^{1}$

\section{Comparison with other clinical studies}

In agreement with some previous studies, ${ }^{419}$ several nonmodifiable risk factors including the degree of allergen sensitisation were associated with an increased risk of hospital admission with asthma. Several studies have examined the role of respiratory viruses in the exacerbation of asthma leading to hospital admissions or attendance at the emergency room. ${ }^{46-29}$ In agreement with our study, a higher rate of virus detection has been reported in children who were admitted to hospital compared with either asthmatic or non-asthmatic controls. Although most of these studies reported a higher frequency of virus detection than in the current study, many have included younger children of less than 3 years. ${ }^{46} 27$ Studies which recruited older children of a comparable age reported a similar virus detection rate to ours. ${ }^{28} 29$

Allergen exposure has been related to asthma severity in sensitised individuals. ${ }^{514}$ Sporik et al reported that, among children admitted to hospital with an acute asthma attack, those who were sensitised and exposed to dust mite had an increased risk of readmission during the following month. ${ }^{14}$ In our study, six children were readmitted during the 12 month study period. Each of these children was sensitised and exposed to at least one allergen, and three of them were sensitised and exposed to more than one allergen. In the US Inner City Asthma Study, children who were sensitised and highly exposed to cockroach allergen were more likely to be admitted to hospital, had more unscheduled medical visits, and more time off school than either non-exposed or nonsensitised children. ${ }^{5}$ However, in the Childhood Asthma Management Program Study, children sensitised to dog and exposed to high levels of dog allergen were more likely to be admitted to hospital in the univariate analysis but not in the multivariate analysis. ${ }^{30}$

The results of our univariate analysis show that both virus infection and high exposure to inhalant allergens in sensitised individuals are significant risk factors for hospital admission. However, in the multivariate analysis their individual effects were no longer significant, but the combination of these risk factors increased the risk of 
Table 3 Odds ratios $(95 \% \mathrm{Cl}$ ) for risks factors for hospital admission using constructed

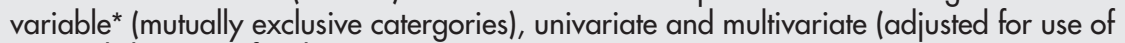
ICS and duration of asthma)

\begin{tabular}{|c|c|c|c|c|}
\hline & \multicolumn{2}{|l|}{ Univariate analysis } & \multicolumn{2}{|l|}{ Multivariate analysis } \\
\hline & OR $(95 \% \mathrm{Cl})$ & $p$ value & OR $(95 \% \mathrm{Cl})$ & p value \\
\hline Sensitised only & 1.8 (0.4 to 9.2$)$ & 0.47 & $1.75(0.3$ to 11.7$)$ & 0.56 \\
\hline Virus only & $3.8(0.7$ to 20.3$)$ & 0.11 & $3.2(0.5$ to 19.1$)$ & 0.20 \\
\hline Sensitised and exposed only & 3.1 (0.97 to 9.7$)$ & 0.06 & $2.6(0.7$ to 9.3$)$ & 0.13 \\
\hline Sensitised and virus only & $12.3(0.7$ to 213.4$)$ & 0.09 & $8.9(0.3$ to 254.2$)$ & 0.20 \\
\hline $\begin{array}{l}\text { Sensitised and exposed and } \\
\text { virus detected }\end{array}$ & 22.7 (4.6 to 112.5$)$ & $<0.001$ & 19.4 (3.7 to 101.5$)$ & $<0.001$ \\
\hline On regular ICS & $0.2(0.1$ to 0.6$)$ & 0.002 & $0.3(0.08$ to 0.9$)$ & 0.03 \\
\hline Duration of asthma† & $0.8(0.7-0.9)$ & 0.004 & $0.9(0.8-1.1)$ & 0.3 \\
\hline
\end{tabular}

ICS, inhaled corticosteroids.

*Overall $p$ value for the constructed variable is $p<0.001$. The reference category for the constructed variable is neither sensitised nor virus infected ( \pm exposed).

†Median (range) in years; OR refers to decreased risk with each additional year.

hospital admission almost 20 -fold. In a recent study of similar design in adults we found that the risk of hospital admission was also markedly increased (about sixfold) with the combination of sensitisation and current exposure to high levels of sensitising allergens and the presence of virus infection. ${ }^{31}$ It is worth noting that the effect of viruses on sensitised individuals who are exposed to allergen appears much greater in children.

\section{Experimental studies}

Several experimental studies have suggested an interaction between allergens and viruses when individuals are exposed to both factors simultaneously. ${ }^{15}{ }^{32} 33$ Patients with ragweed allergic rhinitis have a significant increase in airway reactivity to both histamine and ragweed antigen when infected with rhinovirus, and a significant increase in late phase response after virus inoculation. ${ }^{32}$ Bronchoalveolar lavage fluid obtained from patients with allergic rhinitis both during the acute virus infection and 1 month later showed significantly enhanced histamine release, tumour necrosis factor $\alpha$, and greater recruitment of eosinophils to the airway 48 hours after local antigen challenge. ${ }^{153}$ These changes were not seen in either non-allergic volunteers infected with rhinovirus and challenged with antigen, allergic individuals challenged with antigen prior to infection, or in allergic individuals infected with virus and sham challenged with saline. Thus, a proposed mechanism for the synergistic effect observed when a sensitised and allergen exposed asthmatic becomes infected with a virus is a synergistic augmentation in pro-inflammatory pathways in the airway which results in augmented bronchial inflammation. The precise mechanisms of this process require further detailed investigation.

In contrast to the above studies in which an interaction was observed, a recent study investigating the effect of inhaling low dose mite allergen for 10 days prior to experimental rhinovirus infection in adults with mild asthma failed to observe any synergism. ${ }^{34}$ However, patients in this study were not exposed to allergen and infected with virus concurrently, and this may explain why there was no interaction in any of the clinical or inflammatory outcomes. These differing experimental data emphasise the importance of carrying out studies on patients following natural infection and real life exposure to allergens.

\section{Limitations of the study}

Ideally, a prospective population based study would be the best study design to evaluate risk factors for hospital admission with an asthma exacerbation, but clearly this would be very difficult and time consuming and therefore a case-control study design was used for practical reasons.
Not all children who were admitted with an exacerbation during the 12 month period of the study took part. Consent was obtained from approximately $67 \%$ of parents and children. However, only 10 parents declined to give informed consent, and the remaining 31 were unable to give consent because the parents were not present in the hospital. This may have introduced some selection bias into the study. We have no information regarding the nature or severity of asthma in these children. It is important to note that there was no difference in age and sex between children who took part and those who did not.

Within the study no attempt was made to match the asthma cases and controls for severity of asthma. However, all the stable asthma controls were recruited from hospital outpatients so their asthma was sufficiently severe to require monitoring in a secondary care setting and not by their primary care physician alone. We were unable to use lung function tests to match AA and SA children as many of them were too young to perform spirometric tests (median age 7 years), and spirometry was not routinely carried out on all patients in the hospital outpatient department. Thus, it may be that some of the findings are not due to the risk factors attributed to them but result from differences in severity of asthma between cases and controls. However, we believe that our cases and controls are relatively well matched for severity as there are similar numbers of children in each group with daily wheeze symptoms, who have been admitted to hospital before with an asthma exacerbation, and the median number of previous admissions was similar in the two groups.

It is also of importance to note that we were unable to carry out a formal statistical test for an interaction between virus infection, allergen exposure, and sensitisation due to the size of the study. We estimate that we would need several thousand children in the study to perform such a three way interaction test. Thus, although our results suggest an additional effect of the combined factors compared with the individual factors, we cannot be sure of a synergistic effect given the tests we have been able to carry out.

\section{Conclusions}

Among potentially modifiable factors, admission to hospital with acute asthma was strongly associated with the combination of sensitisation and current exposure to high levels of sensitising allergens and the presence of virus infection. Neither of these factors alone-nor parental smoking, pet ownership and housing characteristicsincreased the risk for hospital admission. Regular inhaled corticosteroid use was significantly associated with a reduced risk for hospital admission. These results indicate that there appears to be a combined rather than an individual effect of 
natural virus infection and real life allergen exposure in allergic asthmatic children in inducing asthma exacerbations resulting in hospital admission. Strategies to reduce the impact of hospital admission of children with asthma exacerbations should be focused on both the reduction of allergen exposure in sensitised individuals and the development of effective therapies for the prevention or treatment of virus infections.

\section{ACKNOWLEDGEMENTS}

The authors thank all the parents and children who took part in the study and all the paediatric staff at South Manchester University Hospital for allowing them to recruit their patients. Pollen exposure data were kindly supplied by Pollen UK local network monitoring site.

\section{Authors' affiliations}

C S Murray, G Poletti, A Woodcock, A Custovic, Academic Division of Medicine and Surgery South, The University of Manchester, North West Lung Centre, South Manchester University Hospitals NHS Trust,

Manchester, UK

J Morris, Department of Medical Statistics, South Manchester University Hospitals NHS Trust, Manchester, UK

T Kebadze, S L Johnston, Department of Respiratory Medicine, National Heart and Lung Institute, Faculty of Medicine, Imperial College, London, UK

Financial support of viral PCR work was by The British Lung Foundation/ Severin Waterman Family Foundation Lung Research Programme (grant number P00/2).

Competing interests: none declared.

\section{REFERENCES}

1 Doull IJ, Lampe FC, Smith S, et al. Effect of inhaled corticosteroids on episodes of wheezing associated with viral infection in school age children: randomised double blind placebo controlled trial. BMJ 1997;315:858-62.

2 Pollack CV Jr, Pollack ES, Baren JM, et al. A prospective multicenter study of patient factors associated with hospital admission from the emergency department among children with acute asthma. Arch Pediatr Adolesc Med 2002;156:934-40

3 Schatz M, Cook EF, Joshua A, et al. Risk factors for asthma hospitalizations in a managed care organization: development of a clinical prediction rule. Am J Manag Care 2003;9:538-47.

4 Duff AL, Pomeranz ES, Gelber LE, et al. Risk factors for acute wheezing in infants and children: viruses, passive smoke, and IgE antibodies to inhalan allergens. Pediatrics 1993:92:535-40.

5 Rosenstreich DL, Eggleston P, Kattan M, et al. The role of cockroach allergy and exposure to cockroach allergen in causing morbidity among inner-city children with asthma. N Engl I Med 1997;336:1356-63.

6 Minor TE, Dick EC, DeMeo AN, et al. Viruses as precipitants of asthmatic attacks in children. JAMA 1974;227:292-8.

7 Horn ME, Brain EA, Gregg I, et al. Respiratory viral infection and wheezy bronchitis in childhood. Thorax 1979;34:23-8.

8 Beasley R, Coleman ED, Hermon Y, et al. Viral respiratory tract infection and exacerbations of asthma in adult patients. Thorax 1988:43:679-83.

9 Minor TE, Dick EC, Baker JW, et al. Rhinovirus and influenza type A infections as precipitants of asthma. Am Rev Respir Dis 1976;113:149-53.

10 Johnston SL, Pattemore PK, Sanderson G, et al. The relationship between upper respiratory infections and hospital admissions for asthma: a time-trend analysis. Am J Respir Crit Care Med 1996;154:654-60.
11 Nicholson KG, Kent J, Ireland DC. Respiratory viruses and exacerbations of asthma in adults. BMJ 1993;307:982-6.

12 Johnston SL, Pattemore PK, Sanderson G, et al. Community study of role of viral infections in exacerbations of asthma in 9-11 year old children. BMJ 1995:310:1225-9.

13 Rosas I, McCartney HA, Payne RW, et al. Analysis of the relationships between environmental factors (aeroallergens, air pollution, and weather) and asthma emergency admissions to a hospital in Mexico City. Allergy 1998:53:394-401.

14 Sporik R, Platts-Mills TA, Cogswell JJ. Exposure to house dust mite allergen of children admitted to hospital with asthma. Clin Exp Allergy 1993;23:740-6.

15 Calhoun WJ, Dick EC, Schwartz LB, et al. A common cold virus, rhinovirus 16, potentiates airway inflammation after segmental antigen bronchoprovocation in allergic subjects. J Clin Invest 1994;94:2200-8.

16 Anon. Epidemiology standardisation project II. Recommended respiratory disease questionnaires for use with adults and children in epidemiological research. Am Rev Respir Dis 1978;118(Suppl):7-53.

17 Chauhan A, Johnston S. Advances in the diagnosis of respiratory virus infections. In: Skoner DP, ed. Asthma and respiratory infections. New York: Marcel Dekker, 2000:221-44.

18 Keuhr J, Frischer T, Meinert R, et al. Mite allergen exposure is a risk for the incidence of specific sensitization. J Allergy Clin Immunol 1994;94:44-52.

19 Gelber LE, Seltzer LH, Bouzoukis JK, et al. Sensitization and exposure to indoor allergens as risk factors for asthma among patients presenting to hospital. Am Rev Respir Dis 1993;147:573-8.

20 Inham JM, Sporik R, Rose G, et al. Quantitative assessment of exposure to dog (Can f 1) and cat (Fel d 1) allergens: relation to sensitization and asthma among children living in Los Alamos, New Mexico. J Allergy Clin Immunol 1995;96:449-56.

21 Campbell MJ, Holgate ST, Johnston SL. Trends in asthma mortality. BMJ 1997;315:1012.

22 Childhood Asthma Management Program Research Group. Long-term effect of budesonide or nedocromil in children with asthma. N Engl J Med 2000;343:1054-63.

23 Bisgaard H, Gillies J, Groenewald $M$, et al. The effect of inhaled fluticasone propionate in the treatment of young asthmatic children: a dose comparison study. Am J Respir Crit Care Med 1999:160:126-31.

24 Suissa $S$, Ernst $P$, Benayoun $S$, et al. Low-dose inhaled corticosteroids and the prevention of death from asthma. N Engl J Med 2000;343:332-6.

25 Doull IJ. Limitations of maintenance therapy for viral respiratory infectioninduced asthma. J Pediatr 2003;142:S21-5.

26 Rakes GP, Arruda E, Ingram JM, et al. Rhinovirus and respiratory syncytial virus in wheezing children requiring emergency care. $\lg E$ and eosinophil analyses. Am J Respir Crit Care Med 1999;159:785-90

27 Freymuth F, Vabret A, Brouard J, et al. Detection of viral, Chlamydia pneumoniae and Mycoplasma pneumoniae infections in exacerbations of asthma in children. J Clin Virol 1999:13:131-9.

28 Thumerelle C, Deschildre A, Bouquillon C, et al. Role of viruses and atypical bacteria in exacerbations of asthma in hospitalized children: a prospective study in the Nord-Pas de Calais region (France). Pediatr Pulmonol 2003;35:75-82.

29 Heymann PW, Holliday T, Carper BS, et al. Viral infections in relation to age, atopy, and season of admission among children hospitalised for wheezing. $J$ Allergy Clin Immunol 2004;114:239-47.

30 Bacharier LB, Dawson C, Bloomberg GR, et al. Hospitalization for asthma: atopic, pulmonary function, and psychological correlates among participants in the Childhood Asthma Management Program. Pediatrics 2003;112:e85-92.

31 Green RM, Custovic A, Sanderson G, et al. Synergism between allergens and viruses and risk of hospital admission with asthma: case-control study. BMJ 2002:324:763-6.

32 Lemanske RF Jr, Dick EC, Swenson CA, et al. Rhinovirus upper respiratory infection increases airway hyperreactivity and late asthmatic reactions. J Clin Invest 1989;83:1-10.

33 Calhoun WJ, Swenson CA, Dick EC, et al. Experimental rhinovirus 16 infection potentiates histamine release after antigen bronchoprovocation in allergic subjects. Am Rev Respir Dis 1991; 144:1267-73.

34 De Kluijuer J, Evertse CE, Sont JK, et al. Are rhinovirus-induced airway responses in asthma aggravated by chronic allergen exposure? Am J Respir Crit Care Med 2003;168:1174-80. 